J. Gen. Appl. Microbiol. Vol. 3, No. 4, 1957

\title{
THE FERMENTATIVE PRODUCTION OF L-ORNITHINE (Preliminary report)
}

\author{
SHUKUO KINOSHITA, KIYOSHI NAKAYAMA and SHIGEZO UDAKA \\ Tokyo Research Laboratory, Kyowa Fermentation Industry Company \\ Received for publication, Nov. 28, 1957
}

In the previous communications ${ }^{(1),(2)}$, the authors have reported on the accumulation of a large amount of L-glutamic acid from carbohydrate and ammonia source by Micrococcus glutamicus. During the course of mutation studies of a strain of this organism, an amino acid other than glutamic acid was found to be accumulated by an arginine or citrulline requiring-mutant strain. The amino acid accumulated was proved to be L-ornithine by isolation and purification of the fermentation product. L-ornithine, which is known as one of the important intermediates of so-called "ornithine cycle" and arginine biosynthesis, has heretofore never been produced in such a large amount by microorganisms.

The fermented broth, which was examined by paper chromatography and confirmed to contain only one amino acid exclusively, was treated with a strong acidic cation exchange resin, Amberite IR-120, and the amino acid absorbed was eluted with $2 \mathrm{~N} \mathrm{HCl}$. The eluate was concentrated and adjusted to approximately $\mathrm{pH} 6$. After the addition of absolute ethanol in the cold, a fine crystalline precipitate was obtained. This crystal was purified by recrystallization and active carbon treatment. The amino acid thus obtained gave the same $\mathrm{Rf}$ value of an authentic ornithine on a paper chromatogram, and melted at $235-6^{\circ} \mathrm{C}$. Anal. Calculated for $\mathrm{C}_{5} \mathrm{H}_{13} \mathrm{O}_{2} \mathrm{~N}_{2} \mathrm{Cl}: \mathrm{C}, 35.56 ; \mathrm{H}, 7.77 ; \mathrm{N}, 16.60$. Found: C, 35.49; H, 7.40; N, 16.67. $[\alpha]_{\mathrm{D}}^{20} ;+10.9^{\circ}\left(\mathrm{C}=5.5, \mathrm{H}_{2} \mathrm{O}\right)$. These analytical data are in accordance with the literature values of L-ornithine. The expected amount of $\mathrm{CO}_{2}$ was also evolved from a sample solution by an L-ornithine decarboxylase preparation of Clostridium septicum P. III (NCTC No. 547) ${ }^{3)}$.

The fermentative production of L-ornithine was successfully conducted as follows: the medium contained $10 \%$ glucose, $0.1 \% \mathrm{~K}_{2} \mathrm{HPO}_{4}, 0.025 \% \mathrm{MgSO}_{4}$. $7 \mathrm{H}_{2} \mathrm{O}, 1.0 \% \mathrm{NH}_{4} \mathrm{Cl}, 0.3 \%$ urea, $0.5 \%$ corn steep liquor, $1.0 \% \mathrm{NZ}$-amine, $0.0015 \%$ phenol red. The $\mathrm{pH}$ was adjusted to 7 . Twenty $\mathrm{ml}$ of this medium was dispensed in a $250-\mathrm{ml}$ Erlenmeyer flask and inoculated with $5 \%$ of inoculum broth. The organism was cultured at $28^{\circ} \mathrm{C}$ on a rotary shaker. The $\mathrm{pH}$ of the culture medium was maintained at a state of neutrality with the addition of a small amount of $20 \%$ urea solution. The course of this fermentation is presented in Table 1 . The quantitative determination of ornithine was carried out by the method of Chinard ${ }^{4}$.

As shown above, about 0.36 mole of $\mathrm{L}$-ornithine was produced from 1 
Table 1. The course of L-ornithine fermentation.

\begin{tabular}{c|c|c|c|c|c}
\hline Incubation time & Glucose & L-Ornithine & $\begin{array}{c}\text { L-Glutamic } \\
\text { acid }\end{array}$ & $\begin{array}{c}\alpha \text {-Ketoglutaric } \\
\text { acid }\end{array}$ & Lactic acid \\
\hline $\begin{array}{c}\text { hours } \\
0\end{array}$ & $\%$ & $\mathrm{mg} / \mathrm{ml}$ & $\mathrm{mg} / \mathrm{ml}$ & $\mathrm{mg} / \mathrm{ml}$ & $\mathrm{mg} / \mathrm{ml}$ \\
24 & 10.0 & - & - & - & - \\
48 & 5.48 & 10.0 & 0 & 1.2 & 5.0 \\
72 & 1.77 & 24.0 & 0.23 & 1.5 & 1.8 \\
& 0.54 & 26.2 & 0.1 & 2.5 & 1.1 \\
\hline
\end{tabular}

mole of glucose. Because of this extremely high yield of ornithine production, the investigation of the mechanism of this fermentation is now in progress.

\section{REFERENCES}

(1) Kinoshita, S., Udaka, S. and Shimonō, M.: J. Gen. Appl. Microbiol. (Japan), 3, 193 (1957).

(2) Kinoshita, S., Tanaka, K., Udaka, S. and Akita, S.: Presented at the International Symposium on Enzyme Chemistry, October, 1957.

(3) Gale, E. F.: Biochem. J. 41, vii (1947).

(4) Chinard, F. P.: J. Biol. Chem., 199, 91 (1952). 